ROCZNIKI NAUK SPOŁECZNYCH

Tom 13(49), numer 3 - 2021

DOI: https://doi.org/10.18290/rns21493.5

OLGA BIAŁEK-SZWED

\title{
ŻYCIE CODZIENNE PODCZAS PANDEMII COVID-19 W PERSPEKTYWIE WSPÓŁCZESNEJ POLSKIEJ PRASY
}

\section{WPROWADZENIE}

Pandemia Covid-19 wpłynęła na życie zawodowe i prywatne większości społeczeństw na całym świecie. W tym czasie media tradycyjne ${ }^{1}$ - rozumiane jako prasa, radio, telewizja (por. Goban-Klas, 2001; Allan, 2006; Ołdakowski, 2010; Szot, 2008; Jeziński, 2009 i inni) - ponownie jak w minionym stuleciu, zaczęły odgrywać ważną rolę pośrednika w kontakcie ze światem zewnętrznym. Nieustająco przekazywały informacje, zarządzenia władz, przestrzegały przed niebezpieczeństwem, doradzały sposoby postępowania, a nawet zdarza się, że pocieszały swoimi treściami. Fakt ten miał istotny wpływ na dobór tematu dokonany przez autorkę niniejszego artykułu.

W polskich mediach ,pandemiczna egzystencja” stała się tematem dominującym od połowy marca 2020 roku, choć już wcześniej Covid-19 zdominował medialną agendę. Potwierdzają to badania ilościowe przeprowadzone przez naukowców z Uniwersytetu Mikołaja Kopernika w Toruniu. Radosław Komuda, Krzysztof Rajda i Jakub Szczepkowski podkreślali w swoich analizach rzecz następującą:

Jak wynika z raportu z badania przeprowadzonego przez agencje Publicon i Press-Service Monitoring Mediów, od połowy stycznia do 12 marca w polskich mediach ukazało się 235 tysięcy publikacji o koronawirusie, a w mediach społecznościowych było ich

Dr Olga BiAŁEK-SZwed - Katolicki Uniwersytet Lubelski Jana Pawła II, Instytut Dziennikarstwa i Zarządzania; adres do korespondencji: Al. Racławickie 14, 20-950 Lublin; e-mail: o.bialek.szwed@wp.pl; ORCID: https://orcid.org/0000-0001-5702-4458.

${ }^{1}$ Ustalenia definicyjne dotyczące mediów tradycyjnych, w rozumieniu Ustawy Prawo prasowe (art. 7), mówią, że prasa to publikacje periodyczne, które nie tworzą zamkniętej całości, takie jak: dzienniki, czasopisma, serwisy agencyjne, ale też stałe przekazy teleksowe, biuletyny, programy radiowe oraz kroniki filmowe, a także wszelkie środki masowego przekazywania, a nawet osoby zajmujące się działalnością dziennikarską. 
aż 1,1 miliona. Liczby te robią duże wrażenie, tym bardziej że dopiero 4 marca w Polsce odnotowano pierwszy przypadek osoby zarażonej wirusem SARS-CoV-2 (Komud i in., 2020, s. 200).

Obecnie media nadal rejestrują i relacjonują wydarzenia związane z koronawirusem, ale obok tego zwiększyła się już produkcja materiałów dziennikarskich na inne, a nie wyłącznie związane z pandemią tematy. Według Dominiki Popielec:

Stan pandemii z powodu koronawirusa niewątpliwie wpłynął na życie społeczne w szerokim ujęciu. Zmiany znacząco wpłynęły na funkcjonowanie mediów, które skupiły się przede wszystkim na informowaniu o statystykach zachorowań w kraju i na świecie, sytuacji w szpitalach, ograniczeniach nałożonych przez rząd. Niestandardowa sytuacja okazała się impulsem do zadawania pytań związanych z działalnością rządów w związku z pandemią COVID-19. Najwięcej wątpliwości pojawiało się w związku z zakupem środków ochrony osobistej. Potwierdziły się one w toku śledztw dziennikarskich (Popielec, 2020, s. 15).

Niniejszy artykuł stanowi pewien rodzaj kalendarium wydarzeń, jakie miały miejsce podczas kolejnych fal pandemii koronawirusa w Polsce, a zostały zauważone, odnotowane i przeanalizowane przez reporterów współczesnej polskiej prasy.

Zasadniczą metodą badawczą zastosowaną przez autorkę jest tu analiza zawartości prasy - materiałów pozyskanych przede wszystkim z tygodników („Polityka”, „Newsweek”, „Do Rzeczy”) i dziennika „Gazeta Wyborcza”. Analiza zawartości przekazu - opierając się na klasycznych dla medioznawstwa w Polsce badaniach Walerego Pisarka (1983, s. 29-30), uznających ją za metodę najwłaściwszą do opisu zawartości periodycznych gazet i czasopism masowych - rozumiana jest tu, zgodnie z myślą Pisarka, jako „rozkład” artykułu prasowego oraz wyodrębnianie i charakteryzowanie jego cech, właściwości i elementów, jak i badanie nie tylko jawnych treści przekazu.

W niniejszym artykule analizie poddano publikatory wyłącznie o zasięgu ogólnopolskim, dostępne w punktach kolportażu bezpośredniego, w prenumeracie oraz w formie wydań on-line. Analiza prasoznawcza dotyczy 2020 roku (tj. Od połowy pierwszego kwartału do końca roku) oraz artykułów opublikowanych do połowy 2021 roku. Cezurę czasową wyznacza agenda medialna zdeterminowana przez tematykę Covid-19, która stała się dominująca właśnie od połowy marca 2020 roku, a systematycznie zaczęła ulegać zmniejszaniu w 2021 roku. 


\section{PIERWSZA FALA PANDEMII COVID-19 W POLSCE}

W pierwszym okresie epidemii, tj. w marcu i kwietniu 2020 roku, narracja, jaką prezentowały polskie media, była chaotyczna i dość przypadkowa. Dziennikarze dopiero uczyli się, w jaki sposób prezentować wydarzenia na temat pandemii. Zdarzało się, że pokazywano informacje przypadkowe, które subiektywnie zdawały się pojedynczym dziennikarzom lub wydawcom ważne. Jako że tzw. pierwsza fala pandemii potraktowała społeczeństwo polskie dosyć łagodnie w porównaniu z niektórymi państwami Europy Zachodniej (np. Hiszpanii czy Włoch), dziennikarze w swoich materiałach nie byli zmuszeni opisywać dramatycznych sytuacji ze szpitali, przepełnionych kostnic, niewystarczającej liczby respiratorów, a także trumien. Polscy konsumenci mediów nie byli epatowani zdjęciami ciężarówek wywożących anonimowe trumny w nieznane, jak miało to miejsce we włoskich mediach. Nie musieli pochylać się nad takimi fotografiami, jak chociażby słynne zdjęcie autorstwa Allesandro Gropellego przedstawiające właśnie kolumny wojskowych ciężarówek wywożących z Bergamo trumny ze zmarłymi, które w Polsce zaprezentowała swoim czytelnikom m.in. „Gazeta Wyborcza”.

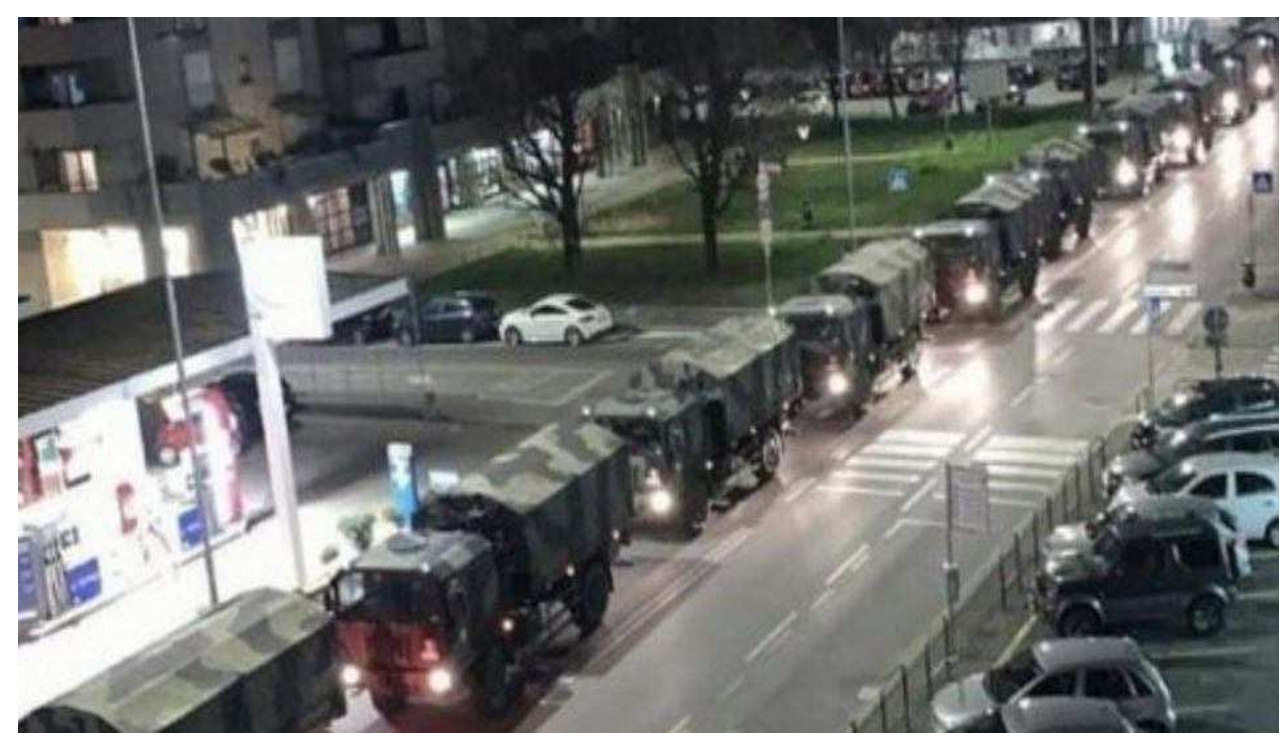

„Kolumny śmierci” w Bergamo we Włoszech

https://wiadomosci.gazeta.pl/wiadomosci/7,173952,25806484,koronawirus-we-wloszechwojskowe-ciezarowki-przewoza-trumny.html [dostęp: 20.03.2020]. 
W pierwszym okresie pandemii dziennikarze polskich mediów skupiali się na opisie wolnych miejsc w szpitalach (tzw. wolnych łóżek), debatowali nad sensem tworzenia kolejnych tzw. Szpital covidowych. Nagłaśniali jednorazowe akcje, takie jak „Posiłek dla medyka” [1, 2, 3]. Przyswajali nowe słowa, nieznane im wcześniej terminy medyczne, które później na stałe weszły do leksyki pojawiającej się w materiałach dziennikarskich. Przykładowo, w początkowym etapie powstawały artykuły metajęzykowe na temat samej nazwy choroby, którą jeszcze w lutym 2020 roku w polskich mediach określano „chińskim koronawirusem” [4]. Pierwszy okres pandemii to także początek procesu wartościowania licznych nazw o prowieniencji medycznej, które zaczęto wykorzystywać w publicystyce medialnej. Przykładowo leksemy takie jak covid czy test, ale też stres, lęk, obawa wartościowano negatywnie, a słowa takie jak np. szczepionka, dezynfekcja, respirator - pozytywnie. Obok terminów wartościowanych jednoznacznie negatywnie lub pozytywnie dziennikarze polskich mediów zaczęli także wykorzystywać w swoich tekstach elementy leksykalne o niejednoznacznej aksjologii, np. nakaz/zakaz, reżim, ograniczenie, dystans, izolacja (zarówno jako przyczyna samotności - wtedy kontekst negatywny [5], jak i jako jedyny w ówczesnym czasie znany sposób na ograniczenie epidemii - wtedy kontekst pozytywny). Interesująca dla badacza mediów jest zmiana w podejściu do wartościowania słowa „szczepionka”. Od zdecydowanie pozytywnej oceny $\mathrm{w}$ publikacjach polskich, zwłaszcza mainstreamowych mediów, w okresie, gdy była ona towarem niedostępnym, a także w kolejnym okresie, gdy stała się towarem reglamentowanym, po czas pełnej dostępności, który zbiegł się z podejrzliwością pojawiającą się głównie w anonimowych publikacjach niszowych mediów [6, 7, 8, 9], kolportowanych dalej na licznych profilach w mediach społecznościowych.

W pierwszym okresie pandemii Covid-19 w Polsce na zawartość mediów składały się również artykuły opisujące trudy zdeterminowanej ograniczeniami codzienności. Miały one niezwykle symptomatyczne tytuły, takie jak przykładowo: Życie w czasach zarazy [10], Pandemia po polsku [11], Sieć i czekaj [12], Państwo (prawie) stanęto [13], Zdolni do zdalnej [14], Nagła śmierć Schengen [15], Sklepy pod specjalnym nadzorem [16]. Przekaz w wymienionych tekstach był tak budowany, aby jak najbardziej uwiarygodnić prezentowaną historię, w niektórych można zauważyć próbę realizacji celu eskapicznego, „ku pokrzepieniu serc” przerażonych, zagubionych czytelników. Widocznym przykładem tak prowadzonej narracji był news z 14 kwietnia 2020 roku, który ukazał się w większości polskich mediów, na temat przylotu największego samolotu świata, zaopatrzonego w asortyment zabezpieczający 
przed zarażeniem się wirusem. Podobne zadanie miały spełniać historie na temat kolejnych tarcz antykryzysowych, pojedynczych bohaterów walczących z pandemią oraz materiały na temat artystów czy też anonimowych osób wywieszających na budynkach plakaty i tworzących wielkie napisy o optymistycznej treści, np.: „Damy radę”, „Jutro będzie lepiej”, „Jeszcze będzie przepięknie, jeszcze będzie wspaniale" [17] itd.

Równie często tematami podejmowanymi w polskich mediach w czasie pierwszej fali pandemii były nieustające dyskusje o asortymencie nieodłącznie związanym z ,pandemiczną” egzystencją, takim jak maseczki i testy [18, 19, 20, $21,22,23,24]$, ale też publikacje opisujące perturbacje związane ze zdalną nauką [25, 26, 27], znacznie utrudnionym dostępem do publicznej służby zdrowia [28, 29, 30, 31, 32], hejtem na wybrane grupy społeczne (np. tzw. Ozdrowieńców [33] lub medyków [34]), skomplikowanym procesem planowania wyjazdów urlopowych [35, 36, 37, 38, 39, 40, 41], a nawet planów matrymonialnych $[42,43]$. Wśród artykułów pochodzących z tego okresu pandemii znajdziemy również, niezwykłe jak na współczesne, masowe, newsowe dziennikarstwo statyczne, zapisy ciszy lub opisy pustki wielkich miast $[13,44$, $45,46]$ oraz materiały na tak abstrakcyjne tematy w perspektywie medialnej, jak niepewność czy strach [4, 21, 28, 47, 48]. Należy też pamiętać, że początkowy okres pandemii Covid-19 w Polsce to także czas specyficznej, niejako „,pandemicznej” kampanii prezydenckiej oraz pierwszej i drugiej tury wyborów prezydenckich, które również stały się dominantą kompozycyjną licznych artykułów medialnych $[49,50,51,52,53,54,55,56,57,58,59,60]$. Punktem przesilenia czy zwieńczenia pierwszej fali w polskich mediach drukowanych był moment tzw. odmrażania gospodarki, czyli powolnego wychodzenia z ograniczeń wynikających z trwającego od końca marca 2020 roku lockdownu. Dziennikarze w swoich materiałach analizowali zaistniałą sytuację, zastanawiali się, czy moment wybrany przez rządzących jest odpowiedni, by zdejmować blokady społeczne. Publicyści, zbierając materiały do swoich tekstów, konsultowali się z epidemiologami, psychologami, politykami, analitykami i matematykami, nawiązywali także do sytuacji oraz do decyzji podejmowanych przez rządy innych krajów europejskich [61, 62, 63, 64, 65, 66]. 


\section{DRUGA FALA PANDEMII COVID-19 W POLSCE}

Druga fala pandemii Covid-19 w Polsce (jesień/zima 2020 roku) wykazała zdecydowanie lepsze przygotowanie mediów do opisu rejestrowanej rzeczywistości. Dziennikarze nie skupiali się już na jednorazowych, nic nie wnoszących do ogólnej sytuacji akcjach, ale zwrócono się w stronę elementów istotnych z punktu widzenia całego społeczeństwa. Zaczęto przyglądać się oraz analizować pojedyncze przypadki w polskiej służbie zdrowia, szczególnie w tych oddziałach i specjalizacjach, które były bezpośrednio zaangażowane w zwalczanie epidemii (np. przygotowaniom szpitali na drugą falę pandemii, niedoborom kadry medycznej itp.). Ważnym i dość często realizowanym tematem podczas drugiej fali pandemii w polskiej mediosferze był kryzys wizerunkowy, jaki powstał wokół szpitali tymczasowych, zwłaszcza w kontekście funkcjonowania warszawskiego szpitala MSWiA.

Pierwsze widoczne $\mathrm{w}$ mediach obawy związane $\mathrm{z}$ potencjalnym nadejściem drugiej fali koronawirusa dziennikarze zaczęli odnotowywać już w połowie sierpnia 2020 roku. Był to czas systematycznego wzrostu liczby zachorowań, przy jednoczesnym dość lekceważącym stosunku do sytuacji wykazywanym przez społeczeństwo. Dziennikarze zwracali uwagę na nadal niewystarczające procedury $\mathrm{w}$ postępowaniu $\mathrm{z}$ tzw. pacjentem covidowym, ale też pacjentem nie-covidowym oraz na brak odgórnej koordynacji $\mathrm{w}$ walce $\mathrm{z}$ epidemią [67, 68, 69, 70]. Media informowały też o słabym przygotowaniu szkół do rozpoczęcia roku szkolnego, obawach nauczycieli, niepewności rodziców, a także radości uczniów związanej z powrotem do szkolnych klas w formie stacjonarnej [71, 72, 73, 74]. Coraz większą grupę tekstów zaczęły stanowić materiały próbujące przewidzieć przyszłość [75], w których wyraźnie zaznaczano strach przed jesienną falą, jaki zgłaszali medycy w licznych wywiadach, jak i zaniepokojenie potencjalnych pacjentów. W pierwszej połowie sierpnia 2020 roku Joanna Solska w tygodniku „Polityka” pisała:

Nie nosimy maseczek, nie zachowujemy dystansu i lekceważąc zagrożenie, ułatwiamy wirusowi transmisję. [...] łagodzi się rygory na stadionach [...]. Rząd ignoruje fakt, że coraz częściej ogniskami zakażeń stają się wesela. Ministerstwo Zdrowia udaje, że nie jest zaskoczone rekordem zakażeń (przekroczyliśmy 600 dziennie), a nawet że spodziewa się następnych. [...] Co stanie się jesienią, gdy oprócz koronawirusa narażeni będziemy na zwiększone ataki wirusów zwykłej grypy? (2020, s. 10).

W tzw. szczycie jesiennej fali media poza artykułami typowymi dla tego okresu, czyli omawiającymi dobowe statystyki wynikające z kolejnych zakażeń, 
ozdrowień, zgonów, zaczęły podawać informacje na temat szczepionek. Były to pierwsze od dłuższego czasu tak optymistyczne w swojej wymowie treści. $\mathrm{Z}$ tego też powodu medialnym wydarzeniem stało się pierwsze szczepienie wykonane w Polsce. Według dr Iwony Sołtys, rzeczniczki prasowej Centralnego Szpitala Klinicznego MSWiA w Warszawie, w którym miało ono miejsce, w wydarzeniu brało udział 150 dziennikarzy, reprezentujących kilkadziesiąt redakcji, zarówno tych największych, jak i mniejszych, o zasięgu lokalnym lub wyłącznie internetowym ${ }^{2}$. Zdaniem I. Sołtys dziennikarzy interesowały najdrobniejsze szczegóły, takie jak otwarcie pierwszej fiolki szczepionki czy wywiad z pierwszą osobą zaszczepioną. Kolejnym wydarzeniem medialnym tego typu były publiczne szczepienia polityków (np. byłego i obecnego marszałka Senatu), które ze szczegółami relacjonowały obok prasy także telewizje komercyjne - Polsat i TVN.

\section{TRZECIA FALA PANDEMII COVID-19 W POLSCE}

O trzeciej fali pandemii koronawirusa w Polsce dziennikarze mediów drukowanych zaczęli pisać w lutym 2021 roku. W artykułach znowu widoczna była niepewność i strach przed tym, co nadejdzie. Już w pierwszych dniach lutego, w „Polityce” Martyna Bunda pisała:

Mamy jeszcze więcej zakażeń. W całej Polsce średnio o połowę więcej niż na początku lutego, a w województwie warmińsko-mazurskim więcej. Liczba nowo zarażonych każdego dnia przekracza 8 tys. osób. W marcu lub na przełomie kwietnia możemy wrócić do sytuacji z jesieni (2021, s. 12).

W tekstach ponownie powrócono do narracji wykorzystującej emocje w warstwie leksykalnej - przykładowe tytuły artykułów z tego okresu brzmiały: Zabójcza trzecia fala [76] czy Same niewiadome [77]. Na kolumnach gazet coraz bardziej widoczne zaczęły być treści prezentujące stanowisko osób krytycznych do obostrzeń [78]. Jeszcze w styczniu restrykcje jeśli były opisywane, to najczęściej w kontekście słuszności ich wprowadzenia. Zdaniem dziennikarzy prasowych za optymistyczny akcent należało uznać fakt lepszej organizacji szpitali niż podczas fali jesiennych zachorowań i oczywiście

\footnotetext{
${ }^{2}$ Informacje na podstawie materiałów własnych autorki, pochodzących z Ogólnopolskiej Konferencji Naukowej zatytułowanej „Współczesne media 12. Współczesne dyskursy medialne”, która odbyła się w dniach 22-23 kwietnia 2021 roku w Instytucie Nauk o Komunikacji Społecznej i Mediach UMCS w Lublinie.
} 
trwające od przełomu roku 2020/2021 szczepienia ochronne [79, 80, 81]. Początek roku 2021 to też czas powstawania artykułów-raportów podsumowujących miniony rok zdeterminowany pandemią Covid-19, w których zaczęto analizować skuteczność strategii walki $\mathrm{z}$ pandemią w Polsce, jak i rozliczać władze z podejmowanych decyzji. Analizy większości mediów zostały oparte - jak przyznawali ich autorzy - „na publicznie dostępnych danych dotyczących zdiagnozowanych przypadków oraz zgonów, restrykcyjności regulacji krajowych i zakresu przestrzegania przez mieszkańców wprowadzonych obostrzeń" (2021, s. 13). Dziennikarze docenili w swoich raportach tempo wprowadzenia restrykcji na początku pandemii, co zapewne spowodowało łagodny przebieg pierwszej fali w Polsce, ale jednocześnie skrytykowali zbyt szybkie tempo luzowania ograniczeń (miało ono miejsce 20 kwietnia 2020 r.), które - jak podejrzewali - było spowodowane przygotowaniami do wyborów prezydenckich. Doceniono także zdyscyplinowanie polskiego społeczeństwa na wiosnę 2020 roku, które okazało się zaskoczeniem dla wielu dziennikarzy. W materiałach zaczęto też coraz częściej zwracać uwagę na postpandemiczną kondycję fizyczną [82, 83, 84], psychiczną [85], a także finansową Polaków [86, 87].

Materiały powstałe podczas najtrudniejszego momentu „trzeciej fali”, czyli od przełomu marca i kwietnia do połowy kwietnia 2021 roku, gdy liczba zachorowań i zgonów była najwyższa, życie codzienne prezentowały jako zagrożenie i nieustanną walkę o przetrwanie. Czytelnik był świadkiem wielu ludzkich dramatów. W prasie niepokój wzmagały liczne nekrologii i pożegnania. Przykładowo „Gazeta Wyborcza” zaczęła zamieszczać specjalny dodatek zatytułowany „Którzy odeszli... Księga pamięci o zmarłych w czasie epidemii COVID-19", poświęcony wyłącznie pożegnaniom osób zmarłych na koronawirusa w Polsce. Dodatek ów można uznać za specyficzną i charakterystyczną dla czasu epidemii Covid-19 w Polsce kronikę wydarzeń. Jego forma, treść i niespotykana dotąd skala, tj. liczba kolumn poświęconych zgonom, uświadamiała czytelnikom dramatyzm wydarzenia.

W maju 2021 roku sytuacja epidemiczna w Polsce poprawiła się na tyle, że w mediach widać było zdecydowanie mniej materiałów na temat zachorowań, zgonów, kwarantann, za to więcej artykułów na temat ozdrowieńców i osób zaszczepionych. Media zaczęły dokładnie pokazywać i omawiać statystyki związane z tzw. stopniem wyszczepienia społeczeństwa. Wraz z rozwojem narodowego programu szczepień na łamach prasy coraz częściej zaczęły być zamieszczane artykuły związane z grupami przeciwników szczepień [88]. 


\section{CZWARTA FALA PANDEMII COVID-19 W POLSCE}

Od końca lipca 2021 roku dziennikarze prasowi zaczęli tworzyć teksty na temat czwartej fali koronawirusa w Polsce i odpowiedzialnemu za nią wariantowi Delta [89]. W wakacje 2021 roku dziennikarze ponownie, podobnie jak rok wcześniej, analizowali i opisywali trudności w planowaniu wyjazdów urlopowych, zwłaszcza tych zagranicznych. Zgodnie ze swoją zawodową powinnością, reporterzy prasowi starali się jak najdokładniej i najaktualniej przedstawiać wymagania poszczególnych państw związane z restrykcjami covidowymi. Dzięki zamieszczanym w prasie raportom odbiorcom w Polsce łatwiej było zweryfikować wymagane dokumenty, kody, zaświadczenia i oświadczenia, które mimo deklaracji polityków nawet w państwach wspólnoty europejskiej nie wszędzie były takie same [90]. W połowie wakacji 2021 roku rozpoczęły się przesunięte o rok, oczywiście z powodu pandemii, igrzyska olimpijskie w Tokio. W „normalnym” czasie temat igrzysk zdominowałby wszystkie kolumny prasowe, zarówno te dedykowane tematom sportowym, jak i niezwiązanym z nim. W aktualnej sytuacji nawet materiały dotyczące tak popularnej tematyki stały się jakby mniej ważne, mniej ekscytujące. Prawdopodobnie zaważyła na tym niepewność, czy w ogóle się rozpoczną, dotrwają do końca, oraz pozbawienie kibiców możliwości bezpośredniego udziału w wydarzeniu [91, 92].

\section{UWAGI KOŃCOWE}

Pandemia koronawirusa SARS-CoV-2, który wywołuje chorobę COVID-19, wymusiła zmiany w wielu obszarach życia większości społeczeństw na świecie. Samoizolacja, dystans społeczny, praca oraz edukacja, ale też konsultacje medyczne prowadzone $\mathrm{w}$ formie on-line, konieczność poddawania się kwarantannie wpłynęły na relacje zawodowe i prywatne. Według badań przeprowadzonych przez niemiecką dziennikarkę pod patronatem Instytutu Goethego:

[...] podczas pandemii wzrosła konsumpcja mediów, [...] Wiadomości stały się formatem chwili i pożądanym we wszystkich możliwych formach prezentacji. Według ankiety przeprowadzonej przez Dział Mediów i Rozrywki firmy doradczej Deloitte, odsetek osób, które codziennie czytają wiadomości [...] wzrósł w Niemczech o 35\%. Poza tym coraz więcej użytkowników jest skłonnych płacić za treści. Regularne korzystanie z płatnych treści Premium wzrosło o 25\%, a cyfrowych wydań gazet w formacie PDF lub w aplikacji - nawet o $31 \%$. Renesans przeżyła również telewizja liniowa. 
U 21\% respondentów firmy Deloitte telewizor był włączony codziennie o ponad dwie godziny dłużej niż przed pandemią. Telewizję odkryły dla siebie na nowo nawet najmłodsze grupy docelowe, wśród których konsumpcja telewizji spadała wcześniej w sposób ciągły i znaczący. Około 30\% zwiększyła się też słuchalność stacji radiowych (Schönhöfer, 2021).

Jak wynika $\mathrm{z}$ raportu opracowanego przez MediaCom (GroupM) (Wirtualnemedia.pl, 2020) w Polsce można dostrzec podobną tendencję powrotu do korzystania z mediów tradycyjnych, w tym z prasy drukowanej. Groźba pandemii, możliwości zachorowania przypomniała o mediach tradycyjnych, bowiem według opublikowanego latem 2020 roku badania agencji informacyjnej Reuters domy medialne cieszą się większą wiarygodnością niż media społecznościowe. Większość społeczeństw na świecie doszła do takich wniosków w sytuacji granicznej, potencjalnego, realnego zagrożenia, gdy liczyło się dotarcie do wiarygodnej, rzetelnej i aktualnej, a przy tym otrzymanej w bezpieczny sposób informacji. W roli przewodnika w życiu codziennym w dobie pandemii Covid-19 media tradycyjne - jak się okazało - sprawdziły się nad wyraz bardzo dobrze.

BIBLIOGRAFIA

\section{Literatura}

Allan S. (2006), Kultura newsów, Kraków: Wydawnictwo Uniwersytetu Jagiellońskiego.

Bunda M. (2021), Same niewiadome, Polityka, nr 10, s. 12.

Cieśla J. (2021), Rok z pandemiq, Polityka, nr 10, s. 13.

Goban-Klas T. (2001), Media i komunikowanie masowe. Teorie i analizy prasy, radia, telewizji i Internetu, Warszawa, Kraków: Wydawnictwa Naukowe PWN.

Jeziński M. (2009), Nowe media a media tradycyjne: prasa, reklama, Internet, Toruń: Wydawnictwo Adam Marszałek.

Komud R., Rajda K., Szczepkowski J. (2020), Zdalni-Solidarni w czasach pandemii koronawirusa: analiza akcji i inicjatyw użytkowników Internetu w Polsce, [w:] K. Marcinkiewicz, P. Nowak, D. Popielec, M. Wilk (red.), Koronawirus wyzwaniem wspótczesnego społeczeństwa: media i komunikacja społeczna, Kraków, Wrocław: Wydawnictwo PTKS, s. 201-211.

Ołdakowski K. (2010), Media pod lupa, Kraków: Wydawnictwo WAM.

Pisarek W. (1983), Analiza zawartości prasy, Kraków: Ośrodek Badań Prasoznawczych.

Popielec D. (2020), Dziennikarstwo śledcze w dobie pandemii koronawirusa w Polsce i na świecie, [w:] K. Marcinkiewicz, P. Nowak, D. Popielec, M. Wilk (red.), Koronawirus wyzwaniem wspótczesnego społeczeństwa, Kraków, Wrocław: Wydawnictwo PTKS, s. 15-27.

Schönhöfer P. (2021), Jak wirus zmienit nasze życie, www.meingoethe.de [dostęp: 8.05.2021].

Solska J. (2020), Opadty maski, Polityka, nr 32, s. 10. 
Szot L. (2008), Dziennikarz jako twórca, [w:] M. Sokołowski (red.), Kulturowe kody mediów. Stan obecny i perspektywy rozwoju, Torun: Wydawnictwo Adam Marszałek, s. 310-329.

Wirtualnemedia.pl (2020), Marki w czasie pandemii. Konsumenci nie chca, by promowaty się na koronawirusie, www.wirtualnemedia.pl/artykul/marki-w-czasie-pandemii-konsumenci-nie-chca-bypromowaly-sie-na-koronawirusie [dostęp: 06.06.2020].

\section{Spis artykułów prasowych (materiał badawczy) w porządku chronologicznym}

[1] Żmijewska M. (2020), Gotują 240 positków dla medyków, Gazeta Wyborcza, nr 69, s. 15.

[2] Anannikowa L. (2020), Podaj widzialna rękę, Gazeta Wyborcza - Duży Format, nr 69, s. 2-3.

[3] Kowalewicz T. (2020), Takiego zaangażowania nie było nigdzie indziej, Gazeta Wyborcza - Tygodnik Lublin, nr 119, s. 6-7.

[4] Walewski P. (2020), Epidemia strachu, Polityka, nr 6, s. 58.

[5] [Redakcja], Kwarantanna nie pozostaje bez wptywu na psychike, Polityka, nr 11, s. 63.

[6] Musiał A. (2020), Do produkcji szczepionki AstraZeneca wykorzystała abortowane dziecko, Strona życia. Serwis Fundacji Pro-Prawo do Życia, s. 1.

[7] Niezależna firma ma dowód na szkodliwość szczepień, www.proremedium.pl [15.06.2021].

[8] Bezpłodność kobiet przez szczepienia przeciwko Covid-19?, www.odkrywamyzakryte.com [30.06.2021].

[9] Covid, tlenek grafenu i $5 G$ - skutki uboczne wielkiego oszustwa!, www.odkrywamyzakryte.com [29.07.2021].

[10] Grzeszak A. (2020), Życie w czasach zarazy, Polityka, nr 10, s. 15-17.

[11] Kaczorowska K. (2020), Pandemia po polsku, Polityka, nr 12, s. 100-105.

[12] Żelazińska A. (2020), Sieć i czekaj, Polityka, nr 13, s. 64-66.

[13] Krasnowska V., Mazuś M., Ćwieluch J. (2020), Państwo (prawie) stanęło, Polityka, nr 13, s. 11-14.

[14] Sowa A., Kowanda C. (2020), Zdolni do zdalnej, Polityka, nr 13, s. 18-20.

[15] Kołodziejczyk M. (2020), Nagła śmierć Schengen, Polityka, nr 14, s. 86-89.

[16] Solska J. (2020), Sklepy pod specjalnym nadzorem, Polityka, nr 14, s. 39-41.

[17] Hudzik A. (2020), Aktywista na balkonie, Newsweek, nr 17, s. 80-81.

[18] Sałwacka S. (2020), Kilka dni czekała na test na koronawirusa, Gazeta Wyborcza, nr 51, s. 7.

[19] Wieliński B. T. (2020), Koronawirus w Europie, czyli skąd wziąć maseczki, Gazeta Wyborcza, nr 55, s. 11.

[20] Cieśliński P. (2020), Jak się robi testy na korona wirusa, Gazeta Wyborcza, nr 55, s. 20.

[21] Solska J. (2020), Wirusowy stres test, Polityka, nr 11, s. 16-18.

[22] Watoła J. (2020), Ministerstwo oblewa testy, Gazeta Wyborcza, nr 90, s. 3.

[23] Grochal R. (2020), Testujemy wszystkich, bo to dziata, Newsweek, nr 19, s. 30-33.

[24] Turlej E. (2020), Wymazywani, Newsweek, nr 21, s. 32-35.

[25] Cieśla J. (2020), Zdalne dzieci, Polityka, nr 14, s. 20-21.

[26] Cieśla J. (2020), Studia bezdotykowe, Polityka, nr 18, s. 28-30.

[27] Bunda M. (2020), Kreda po ekranie, Polityka, nr 20, s. 32-33.

[28] Watoła J. (2020), Wirus obezwtadnia onkologie, Gazeta Wyborcza, nr 73, s. 5. 
[29] Sowa A., Reszka P. (2020), Stan duszności, Polityka, nr 14, s. 10-13.

[30] Hajnosz I. (2020), Pożegnanie ze stetoskopem, Gazeta Wyborcza - Mój biznes, nr 87, s. 2.

[31] Bunda M. (2020), Kronika cichych śmierci, Polityka, nr 14, s. 10-12.

[32] Staszak K. (2020), Koronawirus i leczenie raka, Gazeta Wyborcza - Poradnik, nr 96, s. 17.

[33] Święchowicz M. (2020), Minusowi, Newsweek, nr 21, s. 24-27.

[34] Latos M. (2020), Dostajemy brawa na balkonach rano, a pogardę w sklepie wieczorem, Gazeta Wyborcza, nr 90, s. 13.

[35] Kowanda C. (2020), Latem nie latam, Polityka, nr 17, s. 36-37.

[36] Grzeszak A. (2020), Lato bez wakacji, Polityka, nr 18, s. 38-40.

[37] Bielecki T. (2020), Jak ocalić wakacje?, Gazeta Wyborcza, nr 113, s. 7.

[38] Kokot M. (2020), Wakacje w cieniu koronawirusa, Gazeta Wyborcza, nr 129, s. 4-5.

[39] Bryła E., Maciejasz D. (2020), Ttumy rusza w Polskę, Gazeta Wyborcza, nr 142, s. 12.

[40] Cieśla J. (2020), Ciszej nad Battykiem, Polityka, nr 29, s. 20-22.

[41] Solska J. (2020), Wakacje z bonami, Polityka, nr 32, s. 37-39.

[42] Turlej E. (2020), Już mi niosa maskę z welonem, Newsweek, nr 19, s. 26-29.

[43] Kołodziejczyk M. (2020), Wirus w bieli, Polityka, nr 32, s. 34-36.

[44] Milewski P. (2020), Pogodne szczury na Brooklynie, Newsweek, nr 13, s. 57-59.

[45] Zalewski T. (2020), Stychać tylko wiewiórki, Polityka”, nr 14, s. 42-44.

[46] Wanat E. (2020), Babilon ucicht, Polityka, nr 17, s. 40-42.

[47] Niewińska A. (2020), Zarażeni panika, Do Rzeczy, nr 10, s. 38-41.

[48] Romanowska D. (2020), Paraliż, Newsweek, nr 17, s. 66-69.

[49] Pawlicka A. (2020), Kampania wirusowa, Newsweek, nr 13, s. 26-29.

[50] Kalukin R. (2020), Patokampania, Polityka, nr 14, s. 14-16.

[51] Naszkowska K. (2020), Wybory powinny być dopiero wiosna przyszłego roku, Gazeta Wyborcza, nr 79, s. 14.

[52] Kondzińska A., Szpala I. (2020), Wybory między Kaczyńskim a Gowinem, Gazeta Wyborcza, nr 81, s. 4-5. [53] Grochal R. (2020), Wirusowa diagnoza prezesa, Newsweek, nr 17, s. 18-21.

[54] Wielowieyska D. (2020), PiS: wybory lub stan wyjątkowy, Gazeta Wyborcza, nr 96, s. 3.

[55] Wroński P. (2020), Kandydaci chca wyborów 28 czerwca, Gazeta Wyborcza, nr 125, s. 9.

[56] Kowalewska J. (2020), Trzeba włożyć maseczkę i głosować, Gazeta Wyborcza, nr 148, s. 11.

[57] Kublik A. (2020), Duda już nie walczy o nieprzekonanych, Gazeta Wyborcza, nr 148, s. 9.

[58] Kublik A., Szostak V. (2020), Hybrydowa debata prezydencka, Gazeta Wyborcza, nr 156, s. 3.

[59] Machowski A. (2020), Na kogo zagłosuja wyborcy Hołowni, Bosaka i Biedronia?, Gazeta Wyborcza, nr 156, s. 14.

[60] Sulowski K., Pietraszewski M. (2020), Polska poszła do urn, Gazeta Wyborcza, nr 162, s. 4-5.

[61] Jałochowski K. (2020), Po drugiej stronie krzywej, Polityka, nr 17, s. 16-19.

[62] Wójcik Ł. (2020), Ryzyko otwarcia, Polityka, nr 18, s. 10-12.

[63] Solska J. (2020), Odmrażanie na goraco, Polityka, nr 19, s. 34-36.

[64] Mazuś M. (2020), W uchyleniu, Polityka, nr 19, s. 22-25. 
[65] Nowicki M. (2020), Powrót do nienormalności, Newsweek, nr 21, s. 46-48.

[66] Piątek M. (2020), Sceny z rozmrażania, Polityka, nr 19, s. 84-89.

[67] Watoła J. (2020), NFZ wstrzymuje leczenie, Gazeta Wyborcza, nr 243, s. 4.

[68] Domagała M. (2020), W szpitalach $i$ w szkołach Lublin walczy z pandemia, Gazeta Wyborcza - Tygodnik Lublin, nr 243, s. 3.

[69] Watoła J. (2020), Katastrofa w sanepidzie, Gazeta Wyborcza, nr 245, s, 6.

[70] Kolińska-Dąbrowska M. (2020), Fikcyjne leczenie na odległość, Gazeta Wyborcza, nr 265, s. 12.

[71] Karwowska A. (2020), Nauka ma wrócić do normalności, Gazeta Wyborcza, nr 195, s. 17.

[72] Słowik K. (2020), Szkoła? Poczekajmy dwa tygodnie, Gazeta Wyborcza, nr 195, s. 7.

[73] Karwowska A. (2020), Jak groźny jest koronawirus dla nauczycieli, Gazeta Wyborcza, nr 207, s. 15.

[74] Kossobudzka M. (2020), Szkoty roznoszq koronawirusa?, Gazeta Wyborcza, nr 249, s. 22.

[75] Jażdżewski L. (2020), Świat po pandemii, Gazeta Wyborcza, nr 265, s. 9.

[76] Reszka P., Sowa A. (2021), Zabójcza trzecia fala, Polityka, nr 13, s. 10.

[77] Bunda M. (2021), Same niewiadome, Polityka, nr 10, s. 10-11.

[78] Maciejasz D. (2021), Bunt w Karpaczu, Gazeta Wyborcza, nr 11, s. 13.

[79] Miączyński P. (2021), Kto zdaniem Polaków powinien być pierwszy?, Gazeta Wyborcza, nr 11, s. 5.

[80] Kozłowski P. (2021), Jedyna szansa na powrót do normalności, Gazeta Wyborcza, nr 11, s. 6.

[81] Moskal W. (2021), Wszystko, co chcesz wiedzieć o szczepionce, Gazeta Wyborcza, nr 11, s. 6-7.

[82] Pinkosz K. (2021), Zatrzymać wtóknienie, Do Rzeczy, nr 10, s. 90-91.

[83] Pinkosz K. (2021), Gdy nie można złapać powietrza, Do Rzeczy, nr 10, s. 92-93.

[84] Cieśla J. (2021), Ciężar pandemii, Polityka, nr 13, s. 32-34.

[85] Zaraska M. (2021), Emocjonalna odporność, Polityka, nr 13, s. 68-69.

[86] Cukiernik T. (2021), Odszkodowanie za lockdown, Do Rzeczy, nr 10, s. 78-79.

[87] Grzeszak A. (2021), Kuso z kasa, Polityka, nr 13, s. 50-51.

[88] Bunda M., Sepioło M. (2021), Niezaszczepialni, Polityka, nr 30, s. 12-15.

[89] [brak autora] (2021), Czekając na delte, Polityka, nr 30, s. 11.

[90] Krasnowska V. (2021), Lato z przeszkodami, czyli przewodnik podróżnika, Polityka, nr 27, s. 12-15.

[91] Piątek M. (2021), Przygaszone igrzyska, Polityka, nr 27, s. 82-84.

[92] Leniarski R., Stec R. (2021), To za nich trzymamy mocno kciuki, Gazeta Wyborcza, nr 169, s. 6-7. 


\title{
ŻYCIE CODZIENNE PODCZAS PANDEMII COVID-19 W PERSPEKTYWIE WSPÓŁCZESNEJ POLSKIEJ PRASY
}

\author{
Streszczenie
}

Pandemia Covid-19 wpłynęła na życie zawodowe i prywatne większości społeczeństw na całym świecie. W tym czasie media tradycyjne zaczęły odgrywać ważną rolę pośrednika w kontakcie ze światem zewnętrznym. Niniejszy artykuł stanowi pewien rodzaj kalendarium wydarzeń jakie miały miejsce podczas kolejnych fal pandemii koronawirusa w Polsce, a zostały zauważone, odnotowane i przeanalizowane przez reporterów współczesnej polskiej prasy. Zasadniczą metodą badawczą zastosowaną przez autorkę jest tu analiza prasoznawcza materiałów pozyskanych przede wszystkim z tygodników („Polityka”, „Newsweek”, „Do Rzeczy”) i dziennika „Gazeta Wyborcza”.

Słowa kluczowe: media tradycyjne; prasa; współczesna polska prasa; pandemia; koronawirus.

\section{EVERYDAY LIFE DURING THE COVID-19 PANDEMIC IN THE PERSPECTIVE OF CONTEMPORARY POLISH PRESS}

\section{Summary}

The Covid-19 pandemic has affected the professional and private lives of most societies around the world. At that time, traditional media began to play an important role as an intermediary in contact with the outside world. This article is a kind of calendar of events that took place during the successive waves of the coronavirus pandemic in Poland, and were noticed, recorded and analyzed by reporters of the contemporary Polish press. The main research method used by the author is a press analysis of materials obtained mainly from weekly magazines (Polityka, Newsweek, Do Rzeczy) and the daily Gazeta Wyborcza.

Keywords: traditional media; press; contemporary Polish press; pandemic; coronavirus. 